From a draft. May differ from the published version, which appeared in New Perspectives on the History of Life Sciences and Agriculture, ed. Denise Phillips and Sharon E. Kingsland, 419-439, Springer-Verlag, 2015.

\title{
Breeding Better Peas, Pumpkins, and Peasants: The Practical Mendelism of Erich Tschermak
}

\author{
SANDER GLIBOFF \\ Indiana University
}

\begin{abstract}
This paper follows the career of Erich Tschermak (1871-1962, aka Erich von Tschermak-Seysenegg), one of the three "co-rediscoverers" of Mendel's laws. It considers the practical ramifications, in agriculture, eugenics, and politics, of Tschermak's reading of Mendel's theory, and examines how Tschermak promoted his theories and practices - and himself - in the shifting contexts of the Austro-Hungaian Empire, Austrian First Republic, and Nazi period. Special attention is given to the hybridization work on peas that led him to Mendel's paper, to the development of the "Tschermak Pumpkin" in the 1930s as an illustration of the practical side of his Mendelism, and to his wartime consultations with the German Minister of Agriculture on selecting and crossing strains of crops, animals, and even the peasants to go with them to planned settlements in occupied Poland and Ukraine.
\end{abstract}

Keywords: Genetics, Mendelism, Plant Breeding, Eugenics, Hybridization, Erich von Tschermak-Seysenegg, Biography, Austria, Early $20^{\text {th }}$ Century.

\section{Introduction}

The historiography of Mendelism and early genetics has taken a practical turn in recent years. From the context of sheep breeding in pre-Mendelian Moravia and Mendel's own involvement in scientific agriculture and plant breeding ${ }^{1}$ to the

1. Vítězslav Orel, "Constant Hybrids in Mendel's Research," History and Philosophy of the Life Sciences 20 (1998): 291-299; Roger J. Wood and Vítězslav Orel, Genetic Prehistory in Selective Breeding: A Prelude to Mendel (Oxford: Oxford University Press, 2001); Roger J. Wood and Vítězslav Orel, "Scientific Breeding in Central Europe During the Early Nineteenth Century: Background to Mendel's Later Work," Journal of the History of Biology 38, no. 2 (2005): 239-272. On the current state of the Mendel literature, see Sander Gliboff, "The Many Sides of Gregor Mendel," in Outsider Scientists: Routes to Innovation in Biology, ed. Oren Harman and Michael R. Dietrich (Chicago: University of Chicago Press, 2013). 
leading roles of breeders in Mendel's twentieth-century reception, ${ }^{2}$ historians have come to see practical interests motivating and informing every stage of the theory's and the discipline's development.

With few exceptions, ${ }^{3}$ however, historians of genetics have treated the pivotal event in the story - namely the "rediscovery" of Mendel's work in 1900 - primarily as an intellectual breakthrough. The three co-rediscoverers are celebrated for recognizing the theoretical significance of Gregor Mendel's 1865 paper, particularly its conception of paired intracellular hereditary "elements" or "factors" and its manner of accounting for 3:1 segregation ratios in terms of such factors and their distribution.

Or at least two of the rediscoverers are so celebrated. There has been considerable doubt about how much credit is due Erich Tschermak (18711962, also known as Erich von Tschermak-Seysenegg). Tschermak defended his priority tirelessly. His papers at the Academy of Sciences in Vienna are full of apologetic notes from editors and publishers to whom he evidently had protested when authors referred to Carl Correns and Hugo de Vries as Mendel's two co-rediscoverers. His 1958 memoir even has a special section combating such slights. ${ }^{4}$

2. Barbara A. Kimmelman, "The Influence of Agricultural Practice on the Development of Genetic Theory," Sveriges Utsädesförenings Tidskrift/Journal of the Swedish Seed Association 107 (1997): 178-185; Diane B. Paul and Barbara A. Kimmelman, "Mendel in America: Theory and Practice, 19001919," in The American Development of Biology, ed. Ronald Rainger, Keith R. Benson, and Jane Maienschein (Philadelphia: University of Pennsylvania Press, 1988); Robert C. Olby, "Mendelism: From Hybrids and Trade to a Science," Comptes Rendus de l'Académie des Sciences, Series III: Sciences de la Vie 323, no. 12 (2000): 1043-1051; Garland E Allen, "The Reception of Mendelism in the United States, 1900-1930," Comptes Rendus de l'Académie des Sciences, Series III: Sciences de la Vie 323, no. 12 (2000): 1081-1088; Lisa Onaga, "Toyama Kametaro and Vernon Kellogg: Silkworm Inheritance in Japan, Siam, and the United States, 1900-1912," Journal of the History of Biology 43, no. 2 (2010): 215-264.

3. E.g., Jonathan Harwood, "The Rediscovery of Mendelism in Agricultural Context: Erich von Tschermak as Plant-Breeder," Comptes Rendus de l'Académie des Sciences, Series III: Sciences de la Vie 323, no. 12 (2000): 1061-1067.

4. Erich von Tschermak-Seysenegg, Leben und Wirken eines Österreichischen Pflanzenzüchters: Beitrag zur Geschichte der Wiederentdeckung der 
Nonetheless, he was the last of the three to publish, and his initial explanation of segregation is indeed rather hard to follow or even to find in his ninety-page paper of 1900, and there is no trace at all in that paper of any hypothetical intracellular elements or factors like Mendel's. ${ }^{5}$ His detractors conclude from this that he must not have understood Mendel on these crucial points and should therefore not count among the rediscoverers. ${ }^{6}$

This is, however, an extremely uncharitable and selective reading of Tschermak. And it demands that any rediscoverer worthy of full credit accept a particular physical interpretation of the hereditary factors and how they paired up and separated again - essentially that given by Correns in his rediscovery paper. Whereas Mendel himself had avoided an explicit commitment to hereditary particles, ${ }^{7}$ Correns ascribed to him a system of discrete hereditary/developmental Anlagen that paired up in the nucleus after fertilization, interacted directly so as to allow one of each pair to dominate the other, and parted company during meiosis. ${ }^{8}$ Yet one did not have to embrace such a model to count as a good Mendelian in the early years of the field. Even Thomas Hunt Morgan resisted as late as $1909 .{ }^{9}$ It does not seem reasonable to make it

Mendelschen Gesetze und ihre Anwendung in der Pflanzenzüchtung (Berlin: Paul Parey, 1958), 58-59.

5. Erich Tschermak, "Ueber künstliche Kreuzung bei Pisum sativum," Zeitschrift für das landwirtschaftliche Versuchswesen in Österreich 3 (1900): 465-555.

6. Curt Stern and Eva R. Sherwood, eds., The Origin of Genetics: A Mendel Source Book (San Francisco: W. H. Freeman, 1966), xi-xii; Floyd Monaghan and Alain Corcos, "Tschermak: A Non-Discoverer of Mendelism, I: An Historical Note," Journal of Heredity 77 (1986): 468-469; Floyd Monaghan and Alain Corcos, "Tschermak: A Non-Discoverer of Mendelism, II: A Critique," Journal of Heredity 78 (1987): 208-210.

7. Robert C. Olby, "Mendel No Mendelian?" History of Science 17 (1979): $53-72$.

8. Carl Correns, "G. Mendel's Regel über das Verhalten der Nachkommenschaft der Rassenbastarde" (1900), in Fundamenta Genetica: The Revised Edition of Mendel's Classic Paper, With a Collection of 27 Original Papers Published During the Rediscovery Era, ed. Jaroslav Křǐženecký, with an intro. by Bohumil Němec (Prague: Czechoslovak Academy of Sciences, 1965), 108-109.

9. Thomas Hunt Morgan, "What are 'Factors' in Mendelian Explanations?" American Breeders Association Reports 5 (1909): 365-368. 
the norm for 1900. It belongs rather to the twentieth-century reinterpretation than the rediscovery of Mendel

His early agnosticism about segregating particles is not Tschermak's only posthumous problem. His practical orientation and relative disinterest in theory or in discipline building in genetics have also contributed to his lower status among the rediscoverers. But now, given the practical turn in the literature, perhaps the time has come to reevaluate Tschermak and better integrate the plant breeder into the rediscovery story and early genetics. In particular, I would like to put aside the question of whether he understood segregation properly (or what a "proper" understanding should even have been in 1900) and focus instead on his practical use of it as a tool in plant breeding, a justification for his favored breeding methods, and leverage for advancing his career.

After 1900, hybridization and Mendelian segregation served Tschermak as guiding principles in the design of practical breeding programs. For Mendel had made no explicit provision for his hereditary factors to vary. He explained variation (and, in a limited way, evolution, too) in terms of changes not in the factors themselves, but in their assortment. Mendelism implied, as it seemed to Tschermak and many others, that the key to breeding new varieties was to seek out existing ones with desirable traits, hybridize them, and get those traits to segregate and reassort in new combinations. ${ }^{10}$

In outline, that was Tschermak's main approach for the rest of his long career at the Agricultural College [Hochschule für Bodenkultur] in Vienna, and he used his status and authority as a rediscoverer of Mendel to promote it. He not only applied it himself, but campaigned to establish a series of new agricultural experimental stations in and around Vienna, Lower Austria, Bohemia, and Moravia, which would be devoted to its use.

In addition to reopening the question of Tschermak's role in the rediscovery and reception of Mendelism, I also wish to provide a brief overview of Tscher-

10. On nineteenth- and early twentieth-century breeding methods and the pros and cons of hybridization, see Liberty Hyde Bailey, Cross-Breeding and Hybridizing: The Philosophy of the Crossing of Plants, Considered With Reference to Their Improvement Under Cultivation, With a brief bibliography of the subject (New York: Rural Publishing, 1892); Harwood, "The Rediscovery of Mendelism in Agricultural Context"; Bert Theunissen, "Darwin and His Pigeons: The Analogy Between Artificial and Natural Selection Revisited," Journal of the History of Biology 45, no. 2 (2012): 179-212; Thomas Wieland, "Scientific Theory and Agricultural Practice: Plant Breeding in Germany from the Late $19^{\text {th }}$ to the Early $20^{\text {th }}$ Century," in "Biology and Agriculture," Journal of the History of Biology 39, no. 2 (2006): 309-343. 
mak's career, about which very little information has been available in the secondary literature. Least of all seems to be known about Tschermak's Naziera activities. I have found no mention of this subject in his own many memoirs. Secondary accounts tend to follow the pattern of Tschermak's memoirs and trail off by the time of the Anschluss of Austria in $1938 .{ }^{11}$

But Tschermak was still quite active even as he approached his seventieth birthday and his emeritisation. His correspondence shows him consulting with the German Ministry of Agriculture on selecting and crossing strains of crops, animals, and even the peasants to go with them to planned settlements in occupied Eastern Europe. He also applied the principles of Mendelian segregation in a very odd critique of the Nuremberg marriage-restriction laws.

\section{Early Life and Education}

Erich Tschermak was born into an academic family in Vienna on 15 November 1871. His father was the mineralogist Gustav Tschermak, his grandfather the botanist Eduard Fenzl, who had been one of Mendel's professors. His elder brother Armin would also have a successful academic career, as professor of physiology in Prague, and evidently was always considered the smart one in the family. His elder sister Silvia studied painting and chemistry and worked for a time as an unpaid university Assistentin, but did not have an academic career beyond that. ${ }^{12}$

In 1906, Emperor Francis Joseph elevated Gustav into the hereditary nobility with the formal title of Gustav Tschermak, Edler von Seysenegg, which the family simplified to "von Tschermak-Seysenegg."

Erich Tschermak began his studies in Vienna in 1891, simultaneously at the University and the Agricultural College. Possibly to differentiate himself

11. An exception is Veronika Hofer, "Mendelism and Eugenics in Vienna: Mendel's Rediscoverer Erich Tschermak-Seysenegg and his Active Involvement with Eugenics" (presented at the annual meeting of the History of Science Society, Montreal, Nov. 6, 2010).

12. Unless otherwise noted, biographical information is from TschermakSeysenegg, Leben und Wirken; Peter Ruckenbauer, "E. von TschermakSeysenegg and the Austrian Contribution to Plant Breeding," Vorträge für Pflanzenzüchtung 48 (2000): 31-46; and the editors' introduction to Michal Simunek et al., eds., The Mendelian Dioskuri: Correspondence of Armin with Erich von Tschermak-Seysenegg, 1898-1951 (Prague: Institute of Contemporary History of the Academy of Sciences, Prague, and Department of Genetics/"Mendelianum" of the Moravian Museum, Brno, 2011). 
from his brother, he soon devoted himself entirely to agriculture. After two semesters of study in Vienna, he went to Freiberg in Saxony, Germany, to do a kind of unpaid internship at a large agricultural estate. He was well received there, made the acquaintance of prominent farmers and foresters, and decided to stay in Saxony and finish his studies at the University of Halle. He still did not show much interest in an academic career, but asked to be assigned a quick dissertation topic, so that he could be done with his degree and go back to practical work as soon as possible. His dissertation project was to use dyes and salt solutions to trace the pathways of vascular tissues in woody and herbaceous plants. He seems to have needed his brother's help to get it done in 1896, and it is easy to get the impression from their correspondence, and even from Erich's own accounts, that Armin was the brains of the operation. ${ }^{13}$

Erich Tschermak's father supported him in his career turn to agriculture, allowing him to spend time volunteering at several different seed companies, learning various methods of plant breeding, and most important, making contacts with leading breeders, including Kurt von Rümker and Wilhem Rimpau. ${ }^{14}$ Upon his return to Austria, he was able to speak with considerable authority about German breeding methods and their relative merits. His 1898 survey of current practices there already reveals his preferences and future directions.

Tschermak was looking for scientifically justifiable methods, not just successful rules of thumb. And in addition to improving existing varieties, he wanted to be able to produce new forms without simply waiting and hoping for spontaneous variations to appear or for selection to do its gradual work. He was skeptical of selection alone as a means of producing new forms, but thought it could be used to stabilize and improve varieties created by hybridization or a lucky variation. ${ }^{15}$ He quoted Rimpau to the effect that German breeding

13. For further details on their partnership, see Michal Simunek, Uwe Hoßfeld, and Volker Wissemann, "'Rediscovery' Revised: The Cooperation of Erich and Armin von Tschermak-Seysenegg in the Context of the 'Rediscovery' of Mendel's Laws in 1899-1901," Plant Biology 13, no. 6 (2011): 835-841.

14. For more on whom he worked with and what breeding methods they used, see Harwood, "The Rediscovery of Mendelism in Agricultural Context"; also his own report:Erich Tschermak, "Methoden der Veredelung und Neuzüchtung landwirthschaftlicher Gewächse," Wiener landwirthschaftliche Zeitung: Illustrierte Zeitung für die gesamte Landwirthschaft, Mar. 30, 1898, differs from the offprint in the Österreichische Nationalbibliothek.

15. Tschermak, "Methoden der Veredelung und Neuzüchtung landwirthschaftlicher Gewächse," especially 3-8. 
methodology (particularly for grain) was still in its infancy, and lamented that the Germans were still far ahead of the Austrians, who had hardly even begun to use hybridization: "The method that underlies grain breeding everywhere in Austria is that of selection alone. No experiments with hybridization have been made at all, at least not in practical operations." 16 Tschermak's ambition was to change all that.

In 1898, one of his father's connections at the University of Ghent talked him into going there, but he did not find the expected opportunities for agricultural field work in the nearby countryside. Instead, he asked to do some crossing experiments in Ghent at the city's botanical gardens. He had no particular research question in mind, but the director of the gardens suggested to him that he read Darwin's Effects of Cross and Self Fertilisation in the Vegetable Kingdom for inspiration. So, with the intention of investigating inbreeding depression and hybrid vigor, he chose to work on peas, because they normally self-pollinate, but could also be crossed by hand. He chose pea varieties of different colors, shapes, plant heights, and flower colors, coincidentally much like Mendel's selections.

For Tschermak, however, experimental work was secondary in importance to making the rounds of the major plant breeders and seed companies of western Europe, so he left for an extended stay at the firm of Vilmorin and Andrieux in Paris ${ }^{17}$ without harvesting his results. He left instructions for a gardener to pack up the peas and mail them to Vienna.

Before returning to Vienna, Tschermak took the time to visit breeders in London and Amsterdam, too. In Amsterdam, he called on future co-rediscoverer Hugo de Vries, who showed him his Oenothera mutants. Tschermak later wrote that he was glad he had not brought up the subject of his pea crosses on this visit, because de Vries might have explained their significance to him and made it impossible for him to claim an independent role in the rediscovery of Mendel. ${ }^{18}$ The story of this twist of fate might support his claim of independence from de Vries, but at the expense of making his approach to the pea experiments seem rather haphazard. That they replicated Mendel's work looks all the more like

16. Ibid., 22.

17. On the Vilmorins and what Tschermak would have learned from them about the importance of hybridization, see Jean Gayon and Doris T. Zallen, "The Role of the Vilmorin Company in the Promotion and Diffusion of the Experimental Science of Heredity in France, 1840-1920," Journal of the History of Biology 31, no. 2 (1998): 241-262.

18. Tschermak-Seysenegg, Leben und Wirken, 47-48. 
a case of chance, contra Pasteur's adage, favoring the unprepared mind.

\section{Rediscovery Revisited}

Luckily, the pea collection from Ghent reached Tschermak in Vienna intact. In 1899, while volunteering at an imperial farm in Esslingen, Lower Austria [now Essling, Vienna], he found time and space to continue the crossing experiments, raise a second generation from the hybrids, and perform backcrosses of hybrids to pure recessive parents, unwittingly replicating some of Mendel's trials. He was astounded, at first, to get 3:1 ratios repeatedly in the former and 1:1 in the latter, but upon returning to Vienna in Winter of 1899, his literature search led him to Wilhelm Focke's compendium on hybridization and its discussion of Mendel's paper. He found Mendel's paper at the University library, and the rest is history. Or at least that is how he later liked to remember it. ${ }^{19}$ The memoirs differ somewhat from the published account of his experiments from 1900, in which the Mendelian ratios were not quite so consistent and Tschermak was much more cautious in his embrace of Mendel.

He wrote up his results first as his Habilitationsschrift, the postdoctoral thesis required for teaching at the university level, which he handed in in January 1900. While he was waiting for it to be accepted, the other rediscovery papers (two by de Vries and one by Carl Correns) appeared, and he rushed to publish his own account and crossing results.

Tschermak's publication was not a focused explication of Mendel's laws, but his entire ninety-page thesis. ${ }^{20}$ It was framed as a test of Darwin's ideas about the effects of inbreeding - the original purpose of the Ghent experimentsand the main research question was whether a natural self-pollinator like the pea was immune to inbreeding depression or could be made more vigorous by outcrossing. The Mendel-style crosses and backcrosses seem to have been an afterthought, inspired by some of the literature on hybridization, possibly including Mendel. As Tschermak wrote in 1900:

When, in the course of my work, I became acquainted with additional relevant literature on crosses done with peas, I inserted

19. Tschermak-Seysenegg, Leben und Wirken, 52-53; for other versions in English, see Herbert F. Roberts, Plant Hybridization before Mendel (Princeton: Princeton University Press, 1929), 343-347; and Erich von TschermakSeysenegg, "The Rediscovery of Mendel's Work: An Historical Retrospect," Journal of Heredity 42, no. 4 (1951): 163-171.

20. Tschermak, "Ueber künstliche Kreuzung bei Pisum sativum." 
another series of different experiments that were to study the inheritance of unequally valued [ungleichwerthigen], dominant or recessive (Mendel) traits .... ${ }^{21}$

This suggests a change in direction in mid-project, and helps explain why the paper was not framed as an explication or test of Mendel's laws.

The explications were scattered throughout the paper and dwelt most of all on the rules of dominance. To Tschermak, dominance was a special kind of hereditary value or potency, which he usually called the Werthigkeit of the trait. But the trait's relative power to determine the appearance of a hybrid individual was only one aspect of its Werthigkeit. Segregation, though mentioned nowhere by name, was treated as a second aspect, which determined the numerical preponderance of the higher-valued trait among all the offspring of a hybrid. In Mendel's examples, the traits that were dominant also preponderated in 3:1 ratios, but Tschermak decoupled the two phenomena.

This treatment of segregation has been viewed by later Mendelians as a misunderstanding, but it had certain practical advantages for Tschermak. It unified the Mendelian phenomena under the single concept of Werthigkeit, and it did not commit him to a model of paired hereditary particles that physically segregated from each other and went into equal numbers of gametes. Such a model explained 3:1 ratios perfectly, but what if 3:1 turned out not to be the rule? Tschermak's approach was safer and could easily accommodate other ratios, because it left the physical model entirely out of the discussion.

\section{Mendelism for Breeders}

So what did Tschermak get out of Mendel's paper if not a conception of hereditary elements or particles and their distribution among the gametes? Given that he had learned his practical breeding techniques before 1900, and continued to use the same ones, did he or any breeder really benefit from the new theory? There is reason to believe that Tschermak and other breeders were overstating the direct impact of Mendelian theory on their methods, and that it was actually more useful as a rhetorical tool or emblem of professional status. $^{22}$

\section{Ibid., 466.}

22. Paolo Palladino, "Wizards and Devotees: On the Mendelian Theory of Inheritance and the Professionalization of Agricultural Science in Great Britain and the United States, 1880-1930," History of Science 32, no. 4 (1994): 409-444; Jonathan Harwood, "The Reception of Genetic Theory Among Academic Plant- 
For Tschermak, it was a little of both. He valued Mendelism as a new, scientific justification for his favored hybridization methods, which he was determined to make the standard in Austria. It also gave him some guidance in planning particular crossing programs: how many individual plants to start with and how many of their seeds to sow, given the probability of a desired combination; or which intermediate crossing products would breed true and which harbored hidden recessives.

Certain post-rediscovery developments in hereditary theory further reinforced his case for hybridization over selection. For example, in a 1903 paper on heredity and evolution for breeders, he adopted Wilhelm Johannsen's pure-line theory, under which selection could only sort out pre-existing types or lines from a mixed population, never produce anything really new. As Tschermak put it:

The types within a species and race turn out to be constant, i.e., the constant centers of the range of variation, in spite of all selection. An origination of new types within a species, subspecies, or race is not to be achieved through selection, but occurs either in connection with hybridization (hybrid mutation [Kreuzungsnova]) or through spontaneous mutation. ${ }^{23}$

Rather than wait around for spontaneous mutations, as rival de Vriesians might advise, the best thing for breeders to do, according to Tschermak, was try to create novel hybrids. Most of Tschermak's immediate post-rediscovery publications use Mendelism to provide the theoretical underpinnings for such a practical approach to hybridization. In particular, he favored a method that he associated with the Vilmorins and attributed to Mendel as well: hybridization of varieties with different desirable traits, followed by isolation and inbreeding of individual lines of the hybrid offspring. ${ }^{24}$ The goal was to discover novel

Breeders in Germany, 1900-1930," Sveriges Utsädesförenings Tidskrift/Journal of the Swedish Seed Association 107 (1997): 187-195.

23. Erich Tschermak, "Die Lehre von den formbildenden Faktoren (Variation, Anpassung, Selektion, Mutation, Kreuzung) und ihre Bedeutung für die 'rationelle' Pflanzenzüchtung," Jahrbuch der landwirtschaftlichen Pflanzen- und Tierzüchtung 1 (1903): 30-45, on 36, emphasis original.

24. On Philippe de Vilmorin and French applications of Mendelism that were similar to Tschermak's, see: Christophe Bonneuil, "Mendelism, Plant Breeding and Experimental Cultures: Agriculture and the Development of Genetics in France," Journal of the History of Biology 39, no. 2 (2006): 281-308; but cf. Gayon and Zallen, who do not see Mendelian theory playing such a 
combinations of traits among those isolated lines, or sometimes even novel traits, and to get favored lines to breed true. He developed this method further in his own work and in collaboration with his friend Herman Nilsson-Ehle at Svalöf, Sweden. ${ }^{25}$

Tschermak's status as a co-redisoverer, along with his command of plantbreeding methodology and his international connections, opened unexpected opportunities for him in academia, and he was lured back into the family tradition. Following a series of assistantships and lectureships, he became professor-in-ordinary at the Agricultural College in Vienna in 1909, at the age of 38. He kept that position until his retirement in 1941, but even thereafter he continued to do his research at the College.

Tschermak's post-rediscovery work was mostly along two lines: breeding new varieties and developing guidelines for breeders. Tschermak's message to the breeders was twofold: that they should use Tschermak's preferred methods of hybridization, and that Mendel's laws could help them design their crosses:

Through the renewal of the Mendelian theory of the lawful valuation [Werthigkeit] of traits, the breeding of new, constant plant forms by means of artificial crossing appears placed on a new, rational basis. When these principles are observed, the intentional combination of certain traits from different parental varieties takes shape in a significantly surer and simpler way than with purely empirical methods of crossing and selection. ${ }^{26}$

direct role in French plant breeding.

25. Contra Harwood and Palladino, who play down the influence of genetical theory on agricultural practice, Roll-Hansen argues that the development of this method, particularly at Svalöf, did indeed depend upon Mendelian and pureline theory: Nils Roll-Hansen, "The Role of Genetic Theory in the Success of the Svalöf Plant Breeding Program," Sveriges Utsädesförenings Tidskrift/Journal of the Swedish Seed Association 107 (1997): 196-206. Certainly the scientists themselves insisted on the importance of Mendelian theory:Hermann NilssonEhle, "Einige Züge aus der Entwicklung des Mendelismus," Naturwissenschaften 12, no. 38 (1924): 757-761; Erich von Tschermak-Seysenegg, "Die Einwirkung der Wiederentdeckung der Mendelschen Gesetze auf Pflanzenbau und Pflanzenzüchtung," Kühn-Archiv: Arbeiten aus dem Landwirtschaftlichen Institut der Universität Halle 53 (1940): 1-13; Hans Stubbe, "Erich von TschermakSeysenegg zum 70. Geburtstage," Naturwissenschaften 29, nos. 45-46 (1942): 696.

26. Erich Tschermak, "Ueber Züchtung neuer Getreiderassen mittelst künst- 
But Mendel's laws were highly idealized, and it was not clear just how they could be translated into practice. ${ }^{27}$ Tschermak's approach was to set the idealizations aside and investigate how particular traits really behaved in crosses.

To that end, Tschermak began compiling reference tables of important traits in important varieties - their degrees of dominance, segregation ratios, linkages, etc. - not as predicted by Mendel, but as observed by breeders. For he noted that the same trait might behave differently in different crosses. It might dominate over one alternative from one variety and be recessive to another. The complete dominance, independent assortment, and neat 3:1 segregation ratios observed by Mendel were not presumed to be the norm. ${ }^{28}$

From the rediscovery of Mendel to the Anschluss, Tschermak left a distinct mark on Austrian agriculture. Following a three-month trip to America with Rümker in 1909, to make the rounds of all the major agricultural and evolutionary research stations, from Cold Spring Harbor on Long Island to Luther Burbank's operations in California, he returned with new ideas for improving Austria's research-and-development infrastructure. He was involved in establishing several agricultural research stations. But most of his efforts went into breeding an astonishing number of new varieties of wheat, rye, wheat-rye hybrids, barley, oats, peas and beans, primroses, and many other flowers and vegetables. His winter ryes were especially successful. ${ }^{29}$

\section{Of Pumpkins and Peasants}

In the 1930s, Tschermak got interested in the pumpkins grown in the Austrian province of Styria for their thick, dark green seed-oil, which is prized in Austria as a salad oil. What probably attracted Tschermak's attention to them, aside from their local economic importance, was a mutation that gave the Styrian variety "hull-less" (actually very thin-hulled) seeds. In Tschermak's estimation, it must have arisen spontaneously around 1880 and spread throughout the

licher Kreuzung: Kritisch-historische Betrachtungen," Zeitschrift für das landwirtschaftliche Versuchswesen in Österreich 4 (1901): 1029-1060, on 1029.

27. For more on the actual contributions of Mendelian theory to agricultural practices, see Jonathan Harwood, "Did Mendelism Transform Plant Breeding? Genetic Theory and Breeding Practice, 1900-1945," in this volume.

28. Tschermak, "Züchtung neuer Getreiderassen," 1039-1064.

29. For lists of both his plant-breeding stations and his crop plant varieties, see Ruckenbauer, Tables 1 and 2; also the appendix to Tschermak-Seysenegg, Leben und Wirken. 
region. It also was a good candidate for improvement by means of hybridization, because so many other squash varieties were available with traits that might be combined with their hull-lessness. Tschermak used a vegetable marrow with a bushy growth form, as opposed to the more common long vines and tendrils, to produce what later came to be known as the Tschermak oil pumpkin [Tschermak Ölkürbis]. It had the hull-less, oily seeds of the Styrian pumpkin without the vinous form, so it could be grown in neat rows and harvested more easily by machine. It never caught on in Styria, though, mainly because it also had smaller fruits and smaller seeds than its Styrian parent, but perhaps also because it produced a lighter-colored oil. ${ }^{30}$

After the Anschluss, interest in the Tschermak pumpkin increased, because of cooking-oil shortages and pressure to improve domestic production of seed oils. ${ }^{31}$ In a Nazi-era popularization of his work, Tschermak described how he had added desirable traits to the pumpkin, and he made a pitch for the seeds as both an oil source and an almond ersatz ${ }^{32}$. The light color made the oil

30. Tschermak touted it to Austrian and German farmers in Erich Tschermak-Seysenegg, "Der Kürbis mit schalenlosen Samen: Eine beachtenswerte Oelfrucht," Wiener landwirtschaftliche Zeitung: Illustrierte Zeitung für die gesamte Landwirtschaft, Feb. 17, 1934, 41-42 \& 48-49; Erich TschermakSeysenegg, "Der schalenlose Kürbis als Ölfrucht," Deutsche Landwirtschaftliche Presse: Vereinigt mit: Illustrierte Landwirtschaftliche Zeitung, Feb. 24, 1934, 94. See also recent descriptions by Herwig Teppner, "Cucurbita pepo: History and Thin Coated Seeds," Cucurbit Genetics Cooperative Report 23 (2000): 126-127; Ruckenbauer; Joanna Winkler, "The Origin and Breeding of the Hull-less Seeded Styrian Oil-Pumpkin Varieties in Austria," Cucurbit Genetics Cooperative Report 23 (2000): 101-104; Herwig Teppner, "Notes on Lagenaria and Cucurbita (Cucurbitaceae): Review and New Contributions," Phyton 44, no. 2 (2004): $245-308$.

31. Oil seeds were a priority for Herbert Backe, state secretary (later minister) at the Ministry of Food and Agriculture, who also promoted plantbreeding work at the Kaiser-Wilhelm Society. He served on its senate from 1937 and as its first vice president from 1941 till war's end: Susanne Heim, Calories, Caoutchouc, Careers: Plant Breeding and Agrarian Research in Kaiser-WilhelmInstitutes, 1933-1945, trans. Sorcha O'Hagan (Göttingen: Wallstein, 2003; repr., Springer, 2008), 15-27.

32. Erich von Tschermak-Seysenegg, "Wien als Ausgangsort des praktischen Mendelismus," Böhmen und Mähren: Blatt des Reichsprotektors in Böhmen und Mähren, Juli/August 1942, 242-244, from a copy in the Tschermak Papers, 
more attractive to markets outside of Austria and the seeds more plausible as a substitute for nuts. The home economics unit of the German Women's Welfare Organization developed recipes for pumpkin-seed macaroons and cakes and affirmed of the seeds that, "As an addition to cookies and cakes, and as a cake filling, they will be welcomed by every Hausfrau." 33

Tschermak's pre-Anschluss views on Nazism are difficult to determine. He was never active politically and left little documentation of his opinions, but they probably fell in the center-right, conservative-Catholic region of the Austrian spectrum. Certainly his pro-Nazi colleagues did not treat him like one of their own when they took over the Agricultural College in 1938, but they did not remove him from his position, either, as they did their perceived opponents. At the time of the Anschluss, Tschermak was sixty-six years old, still four years short of the standard retirement age and eager to continue his work and to defend his academic perquisites, regardless of who was running his country or his institution. It did not take him long to figure out how to ingratiate himself with the new authorities.

Nazi sympathizers and secret party members like Tschermak's colleague Franz Sekera had been secretly plotting their takeover of the Agricultural College for several years. Sekera took charge on 12 March 1938, the very day German troops arrived. He promptly had the Rektor arrested, dismissed the few Jewish or half-Jewish students, removed all the professors with known anti-Nazi sentiments, and reinstated any of his fellow "illegals" who had lost their positions in 1934, under the Schuschnigg government. ${ }^{34}$ Within a few months, Sekera was short of rooms for his political appointees and re-appointees, so he set his sights on Tschermak's workspace.

Sekera asked politely, but ominously, for Tschermak to comply with the wishes of his new colleagues and give it up voluntarily:

What matters to me most especially in this whole affair: I would

box 15 from a copy in Nachlaß Erich von Tschermak-Seysenegg, Archiv der Österreichischen Akademie der Wissenschaften, Vienna (henceforth cited as Tschermak Papers), box 15, on 244.

33. Deutsches Frauenwerk, Gau Niederdonau, Kreisstelle Brünn Hauswirtschaftliche Beratungsstelle, "Verwendung von Kürbiskernen im Haushalte," mimeographed flyer, n.d., Tschermak Papers, box 1, folder 77 (filed under "Brünn").

34. Paulus Ebner, "Krise in Permanenz (1918-1945)," in Die Universität für Bodenkultur Wien: Von der Gründung in die Zukunft 1872-1997, ed. Manfred Welan and Paulus Ebner (Vienna: Böhlau, 1997), 112ff. 
like for you, through an act of camaraderie, to show these gentlemen here, who are not quite well disposed toward you, that you stand entirely on our side and have fully gotten over bygone events. You see, honored Court Councilor, how hard I am trying to build a pleasant mode of coexistence at our College.... ${ }^{35}$

Tschermak was wary, but did not rush to comply. He wrote back to Sekera to ask for more time, at least until the end of his spring growing season. ${ }^{36}$ Simultaneously he went over Sekera's head to appeal to State Secretary Anton Reinthaller at Austria's post-Anschluss Ministry of Agriculture, who eventually intervened on his behalf and enabled him to keep his room.

From then on, Tschermak made an effort to stay in the good graces of the Austrian and the Reich Ministries of Food and Agriculture. He made the personal acquaintance of Reichsminister R. Walther Darré, from whom he also received official congratulations and high praise on his seventieth birthday and retirement in 1941. ${ }^{37}$ He also received the "Goethe Medal" [Goethe-Medaille für Kunst und Wissenschaft] from Hitler that year. ${ }^{38}$

As a scientific plant breeder, Tschermak embodied an ideal of the Aryan researcher, learned, but anchored in the practical realm, and in this case in the soil as well. As a high Darré staff member put it in a newspaper article:

In Tschermak, there is a happy combination of knowledge gained at the scholar's desk with practical experiences that he was able to gather through agricultural and gardening work. Thus all the results of his decades-long research serves practical daily life. ${ }^{39}$

35. Franz Sekera to Erich von Tschermak-Seysenegg, May 29, 1938, Tschermak Papers, box 4, folder 95.

36. Erich von Tschermak-Seysenegg to Franz Sekera, May 30, 1938, Tschermak Papers, box 4, folder 95.

37. M. A. Prinzessin Reuß zur Lippe, "Ein Pionier der Vererbungsforschung: Professor Dr. Tschermak von Seysenegg 70 Jahre alt," Nationalsozialistische Landpost: Hauptblatt des Reichsnährstandes, Nov. 14, 1941, 46, from a clipping in the Tschermak Papers, box 12, folder 38.

38. "Der Wiederentdecker der Mendelschen Gesetze: Der Führer verlieh Professor Dr. Tschermak zu seinem 70. Geburtstag die Goethe-Medaille," Captioned portrait of Erich von Tschermak-Seysenegg, Nationalsozialistische Landpost: Hauptblatt des Reichsnährstandes, Nov. 14, 1941, 1, from a clipping in the Tschermak Papers, box 12, folder 38.

39. Reuß zur Lippe, first column on 46. 
Tschermak tried to conform to this ideal. In a letter draft from around this time to an unnamed state secretary (apparently intended for Herbert Backe in Germany) he declared his support for key elements of Darré's Blut und Boden [blood and soil] ideology. He portrayed himself as the just the sort of scholar-farmer that Germany needed, but no one appreciated properly.

Tschermak lamented the low levels of "recognition for plant breeding achievements, which are so important for the food industry, compared to industrial and commercial achievements," and he expressed his delight with the Ministry's conviction that "the balance between city and countryside, which had been shaken, to the detriment of the Volk and the economy, must be restored." He asserted that he deserved the Nobel Prize for his rediscovery of Mendel, but would not be considered for it because he was a farmer [Landwirt], and he hinted that he could use further support for his work. This letter draft is remarkable for the mercenary attitude revealed in handwritten annotations, of which some are in Armin's hand. Erich must have sent it to his big brother for approval and for advice on how to make it "bear even more fruit." 40

But there are also indications that much of the admiration Tschermak professed for Darré was sincere. From the end of 1939 on, when his wife got Darré to inscribe a book for him as a Christmas present, ${ }^{41}$ Tschermak cultivated a friendly relationship with Darré, continually sending him articles on Mendel and Mendelism, and reports on his wheats, ryes, and pumpkins. He joined the Nazi farmers' associations under Darré's aegis, serving on the board [Kuratorium] of the Gesellschaft der Freunde des Deutschen Bauerntums and the council [Landesbauernrat] of his regional Landesbaurnschaft. ${ }^{42}$ When Darré resigned from the government in 1942, under pressure because of food-supply problems and differences with Heinrich Himmler over settlement plans for occupied Eastern Europe, Tschermak expressed his concern, thanked him for years of support, and asked for his home address to continue the correspondence, ${ }^{43}$

40. Erich von Tschermak-Seysenegg to Staatssekretär [Herbert Backe?], typewritten letter draft with handwritten annotations, 1941? Tschermak Papers, box 5, folder 10 (filed with the Sekera letters).

41. I infer this from Darré's response to a thank-you note from Tschermak: R. Walther Darré to Erich von Tschermak-Seysenegg, Jan. 9, 1940, Tschermak Papers, box 1, folder 105.

42. Based on various letters in the Darré folder.

43. Erich von Tschermak-Seysenegg to R. Walther Darré, 1942, Tschermak Papers, box 1, folder 105. 
which he kept up even after the end of the war. ${ }^{44}$

There is one letter draft in which Tschermak discussed Mendelian heredity in humans. It dates from 1942, after Darré had left office. In it, Tschermak first complained about how he still had to fight to keep his lab space, about how the younger generation was not being trained properly and had no respect any more for their elders, and about the failures of the recent university reforms. Then he added that nobody understood the Jewish question properly, either, and he proceeded to explain the principles of Mendelian segregation to Darré, as they applied to Jewish-Aryan intermarriage:

The Jewish question, too, which interests me very much, is dominated by multiple misunderstandings. I am against the inhuman tormenting and killing of the Jews, but surely for the merciless sterilization of all people in the Reich who have even a drop of Jewish blood in them. There are still a lot of $\frac{1}{2}, \frac{1}{4}$ and $\frac{1}{8}$ Jews running around among us, including such as have swindled themselves an Ahnenpass, or were not recognized as Jews, because they knew how to disguise themselves and joined the Party very early.

Tschermak had no faith in bureaucratic methods of keeping track of ancestry, not only because of Jewish trickery, but also because of their supposed promiscuity and adultery. They would frequently father illegitimate half-Jews who are born into unwitting Christian families and recorded as Christian births. It was better, he argued, to identify the part-Jews by their Jewish looks and behavioral traits than by their recorded parentage, even at the risk of misclassifying the occasional Christian.

Tschermak's real problem with part-Jews - and here he could speak with the authority of the great hybridizer - had to do with the rules of segregation, and what happened if you let them marry each other, as they were wont to do:

The Jews really must be able to smell or feel each other out, because usually $\frac{1}{2}, \frac{1}{4}, \frac{1}{8}$ Jew-mixtures marry among themselves all over again, for which reason absolutely pure Jews or more of the awful Jewmixtures must Mendelize out of such marriages! $!^{45}$

44. One last letter draft in the collection is from 1951 and still addresses Darré as Herr Minister.

45. Original text: "Auch in der mich sehr interessierenden Judenfrage herrscht noch vielfach Unverständnis. Ich bin gegen das unmenschliche Quälen und Töten der Juden, wohl aber für die unbarmherzige Sterilisierung aller Menschen im Reiche, die auch nur einen Tropfen jüdischen Blutes in sich haben. Es laufen bei uns noch eine Menge $\frac{1}{2}, \frac{1}{4}$ and $\frac{1}{8}$ Juden herum, auch solche die sich 
Ironically, if Tschermak had described the inheritance of pea coloration in this manner in 1900, that might have earned him more respect from critics who said he did not understand how segregation was supposed to work. But for 1942, and for complex human cultural characteristics, it is an astonishingly primitive view. ${ }^{46}$ He had nothing to gain by feigning such a view to impress Darré, since the latter was out of office and out of favor. It would seem that he thought about intermarriage the way he thought about practical breeding, where hybridization was a means of breaking a type.

Tschermak left us one more Nazi-era discussion of human breeding, in an eight-page draft of "Remarks on the future task of German settlement in the East," co-authored with Armin. It is undated, and there is no indication of what, if anything, it was ever used for, but it seems likely to have been written for Darré or maybe his more-ruthless successor, Backe, who is known for his eponymous plan to divert Soviet food supplies and starve most of Russia. ${ }^{47}$

In this document, the brothers Tschermak focused on:

Questions of soil, water, and climate, further, questions of management and usage [Wirtschaftsweise], of mechanical and financial resources, of plant- and animal production and breeding, and finally of settler selection and of course settler production. ${ }^{48}$

ihren Ahnenpass erschwindelt haben, oder weil sie es verstanden hatten sich zu tarnen und sich sehr frühzeitig der Partei angeschlossen hatten, nicht als Juden erkannt wurden... Die Juden müssen sich gegenseitig wirklich riechen oder tasten, denn meistens heiraten wieder $\frac{1}{2}, \frac{1}{4}, \frac{1}{8}$ Judenmischlinge untereinander, weshalb wieder absolut reine oder noch arge Judenmischlinge aus solchen Ehen wieder herausmendeln müssen! "Erich von Tschermak-Seysenegg to R. Walther Darré, Dec. 26, 1942, Tschermak Papers, box 1, folder 105, emphasis original.

46. Not that there weren't any American eugenicists left who still conceived of "feeblemindedness" or other ill-defined mental and moral traits as simple Mendelian recessives, but no one with Tschermak's experience and status as a founder of modern Mendelism.

47. For more on such plans and the technocratic logic behind them, see Götz Aly and Susanne Heim, Vordenker der Vernichtung: Auschwitz und die deutschen Pläne für eine neue europäische Ordnung (Hamburg: Hoffmann \& Campe, 1991); English version: Götz Aly and Susanne Heim, Architects of Annihilation: Auschwitz and the Logic of Destruction, trans. A. G. Blunden (Princeton: Princeton University Press, 2002).

48. Erich von Tschermak-Seysenegg and Armin von Tschermak-Seysenegg, 
They avoided military matters and wrote as if the land to the east, from Poland through the Ukraine to the Black Sea, were uninhabited. Their description of the territory skirted Russia proper, perhaps an indication that it dated from after June 1941 and the end of the Nazi-Soviet non-aggression pact, but before the siege of Leningrad, which began in September.

Concerning plant- and animal breeding, they pointed out how varied the terrain and climate were in that large territory, so that the challenge, at least in the short run, would be to find appropriate existing breeds for each situation, rather than to breed new varieties. They took the opportunity to plug Erich's work and the likely usefulness of his ryes, wheats, and barleys, and even his oil pumpkins, for the eastern settlements. For the longer term, they made a pitch for establishing more agricultural research stations to test and breed new varieties. They praised the work of Nicolai Vavilov in Leningrad and his extensive seed collections as resources for new hybridization efforts, but stopped short of saying they should be raided (perhaps another indication that German troops had not yet attacked Leningrad). Instead they opined that there would surely be some abandoned breeding stations in the occupied territories, where locally adapted varieties would be found that would be worth trying out. ${ }^{49}$

When they took up the subject of selecting and breeding settlers, all talk of hybridization came to an end. Local adaptation was still a consideration, however. Their first preference was to recruit ethnic Germans already living in Ukrainian and Russian territories, whose availability should be provided for explicitly in the eventual peace agreement. Their second choices would have been ethnic Germans who had successfully migrated to other places and maintained their German-ness there. From among these, those most willing to migrate, and younger sons of farmers, should be recruited first. Further consideration should be given to identifying talented organizers and leaders among the settlers, sending enough skilled workers and professionals along with the farmers, keeping members of pre-existing communities or coreligionists together, and maybe even sending convicts or other forced migrants (but to strictly segregated settlements). ${ }^{50}$

Finally the authors turned from the recruiting of new settlers to the planning of their (re)production [planmässige Siedlerproduktion]. They foresaw strict

"Bemerkungen zu der Zukunftsaufgabe Deutsche Ostsiedlung," typewritten manuscript with manual corrections, n. d. [ca. 1941], Tschermak Papers, box 10, folder 26, 1 .

49. Ibid., $2-4$.

50. Ibid., 6-7. 
observation and classification of their achievements, from which would emerge a hierarchy of fitter and less-fit families. In order to encourage intermarriage within the top level, there could be specially planned social events, and travel stipends to send the fittest farmers' sons to visit or even work on the estates of selected families. Farmers' daughters could also be sent the other way to see how the prospective grooms' families and farms worked. It was all pretty conventional positive eugenics, except perhaps for an unusually strong pitch for organized child care, both to lighten the workload of the parents and to protect the children from being taken out to the fields all day. ${ }^{51}$

Tchermak's collaboration with the Nazi authorities was probably not very consequential - there is no reason to think that his eugenical ideas had any affect on policy or that the Tschermak pumpkin made much of a dent in the cooking-oil shortage, for example - but it was also unprompted and unnecessary. The path of least resistance would have been to scale back his research program in 1938, as Sekera wanted, then lie low, and retire in 1942. No one in authority demanded anything more of him. Instead he sought recognition and resources from the state. He was probably motivated mostly by egotism and opportunism, but he was also genuinely attracted to some aspects of the ideology, especially the value placed on agriculture and the ties of the German people to the soil. The Nazi concepts of racial purity also resonated with his views on the nature of plant varieties and the power of hybridization to modify them.

\section{Postwar Career}

On 24 April 1945, while fighting was still going on in the vicinity of Vienna, a small group of professors met to begin reorganizing and de-Nazifying the Agricultural College. Most of the group had lost their jobs for political reasons in 1938, under Sekera, and they spoke scornfully of their absent colleaguesthe opportunists who had not minded working under the Nazis, but now abandoned ship when there might be consequences to face or danger from bombing. Many of them had headed for the relative safety of the mountain lakes of the Salzkammergut. As one professor later recalled, everyone with reason to fear a liberated Austria had "preferred to set up house on the Wolfgangsee in Upper Austria or someplace in the west until the critical days of the occupation were history." 52 This caricature of the fair-weather faculty fit Tschermak perfectly.

51. Ibid., 7-8.

52. Josef Flatscher in his inaugural address as rector in 1948, translated from Paulus Ebner, "Wiederaufbau und Stabilisierung 1945-1971," in Die 
After the group reinstated Alfred Till and elected him Rektor, ${ }^{53}$ Tschermak wrote to him obliviously from his lakeside cottage on the Wolfgangsee, ${ }^{54}$ in June, about getting his lab back. Despite age and arthritis, he wrote, he believed he would be "able to participate usefully, especially in the area of plant breeding and to serve as a scientific worker and possibly a silent advisor to the Agricultural College." He pointed to all the foreign scientific societies he still belonged to and claimed to be respected in all the occupying countries. He wanted to revive Austrian plant breeding and reconstitute the Society for Plant Breeding (which he had co-founded in $1912,{ }^{55}$ but had been closed down in 1939). All he needed was his ground-floor work space, so he would not have to climb stairs, a small plot of land in the College garden, and maybe a technical assistant. Also, he was worried that someone might have appropriated his bomb-damaged house, and would appreciate it if the College could make official inquiries about that and tell his property manager he wanted to come back. And he wanted a job for his former assistant Franz Frimmel, who was stuck in Czechoslovakia. ${ }^{56}$

After two more letters to Till (with the additional demand to have his pension payments resumed) failed to elicit a response, he turned, in December, to Leopold Figl, Austria's first postwar federal chancellor, who happened to be a graduate of the Agricultural College. Tschermak reminded him that he was a former teacher and said he shared Figl's desire to rebuild his country: "Of course I follow with great interest all the things you went through under the Nazi regime ${ }^{57}$ and how you now, in your position are doing everything you

Universität fur Bodenkultur Wien: Von der Gründung in die Zukunft 1872-1997, ed. Manfred Welan and Paulus Ebner (Vienna: Böhlau, 1997), 142.

53. Ebner, "Krise in Permanenz (1918-1945)," 125; Ebner, "Wiederaufbau und Stabilisierung 1945-1971," 141-142.

54. In St. Wolfgang, not the same town frequented by the Exners and the other academic families discussed by Deborah Coen, but on the same lake:Deborah R. Coen, Vienna in the Age of Uncertainty: Science, Liberalism, and Private Life (Chicago: University of Chicago Press, 2007).

55. Erich Tschermak-Seysenegg, "Zum 25jährigen Bestehen der Gesellschaft für Pflanzenzüchtung 'Z' Wien,” Der Züchter 9, nos. 6-7 (1937): 137-144.

56. Erich von Tschermak-Seysenegg to Alfred Till, typewritten carbon copy, June 15, 1945, Tschermak Papers, box 4, folder 54 (misfiled under Titl).

57 . He had just spent six years in concentration camps and had a death sentence hanging over him when the war ended. 
can to help our poor, shattered Austria onto its feet again." Despite seven job offers from foreign countries over the course of his career, he had always been faithful to his College and his fatherland, yet, he complained, his offer to help out at the College seemed not to resonate there. He claimed to be much in demand at other institutions but wanted to work on rebuilding plant breeding in Vienna and Lower Austria, to reconstitute the Society for Plant Breeding, which the Nazis had shut down, and to see that Frimmel was recruited back from Czechoslovakia. ${ }^{58}$

The response came from Anton Steden, another reinstated colleague at the Agricultural College (forced to resign under Sekera because of suspicion that his wife's grandmother had been Jewish), who was also serving in Figl's government as head of the provisional department of agriculture. ${ }^{59}$ Steden assured Tschermak that his offer of support really had resonated at the College, but added cryptically that: "The College of Agriculture, however, has a right, in this connection, to receive some clarifications, which would be best done through oral discussion after your return." 60

Still at the lake in January, Tschermak was incensed. He complained to Steden again about the lack of response to his earlier letters, all the trouble he had repeatedly had to go to to keep the ground-floor workspace that had been promised to him on his sixtieth birthday because of his arthritis, his pension, and - what Steden probably wanted to talk about - accusations of uncolleagial behavior toward his former Rektor following the latter's dismissal in 1938 . He claimed that he had been the only professor to pay a call on the ex-Rektor, once it was permitted, and had spoken in favor of him being paid his pension. ${ }^{61}$

Tschermak's postwar correspondence reinforces the impression of him as an egotist and opportunist, concerned only with securing resources and privileges, no matter from whom. Still, the speed with which he was able to change his political stances and switch patrons is dizzying.

Despite the friction with Steden, Tschermak got most of what he wanted. Frimmel never got his job in Austria, but was able to stay on in Brün. Tschermak soon returned to Vienna and resumed work at the College and

58. Erich von Tschermak-Seysenegg to Leopold Figl, typewritten carbon copy, Dec. 7, 1945, Tschermak Papers, box 1, folder 126.

59. Ebner, "Krise in Permanenz (1918-1945)," 139.

60. Anton Steden to Erich von Tschermak-Seysenegg, typewritten copy of letter, Jan. 17, 1945, Tschermak Papers, box 1, folder 126.

61. Erich von Tschermak-Seysenegg to Anton Steden, Jan. 24, 1945, Tschermak Papers, box 1, folder 126. 
remained active in plant breeding for many more years. He lived to be almost ninety-one.

\section{Conclusion}

This study was intended to serve two purposes: to use the case of Erich Tschermak to bring out the practical dimension of early Mendelism, and to fill out the biographical picture of Tschermak's post-rediscovery career.

Breeding practice both contributed to Mendel's rediscovery and benefited from it. Young Tschermak had already embarked on a career in plant breeding before 1900, and was led by practical questions about hybrid vigor to begin his hybridizing experiments with peas and read up on pea hybridizers like Mendel. After 1900, he opted not to play a leading role in developing hereditary theory or building the discipline of genetics, but preferred to promote the use of Mendelian principles in plant breeding. I believe his reputation as an independent corediscoverer suffered because of the low profile he maintained in the field of pure genetics, except perhaps for a few years after 1900 .

The breeding method Tschermak promoted emphasized the use of hybridization and the principles of segregation to plan sequences of crosses that would bring together desired traits from pre-existing varieties. For this, he needed his Mendelism to provide a theoretical justification, some practical guidance, and prestige. He had only limited use for theory, and he did not care to play a leading role in the development of the gene concept, chromosome mapping, or even to say much about the physical basis of heredity. The breeding methods were extremely successful, both in creating new and useful crop varieties and in spreading to many experimental breeding stations within the Austro-Hungarian Empire and abroad. His status as a co-rediscoverer and -founder of Mendelism certainly helped promote the method.

Tschermak's status, along with his devotion to practical breeding, paid off in his personal life as well as his research. It opened a niche for him within his academic family and in the Austrian academic world, as the scholar-practitioner. It was not a bad niche to occupy during the Nazi period, when it earned him favor with Darré at the Ministry of Food and Agriculture and kept him in his lab long after he might have been forced into retirement. And it let him make a case for being needed again at the end of the war, to rebuild Austrian agriculture. 


\section{Acknowledgements}

Work on this paper was supported by a grant from the NSF (award no. 0843297). I thank Andy Fiss for research assistance and Jonathan Harwood, Sharon Kingsland, Renate Kasak, and participants in the Biology Studies Reading Group at Indiana University for comments on various drafts. Thanks also to the library staff at the Austrian Academy of Sciences for their friendly support.

\section{Bibliography}

\section{Archives and Manuscript Collections}

Nachlaß Erich von Tschermak-Seysenegg. Archiv der Österreichischen Akademie der Wissenschaften, Vienna.

\section{Published Sources}

Allen, Garland E. "The Reception of Mendelism in the United States, 19001930." Comptes Rendus de l'Académie des Sciences, Series III: Sciences de la Vie 323, no. 12 (2000): 1081-1088.

Aly, Götz and Susanne Heim. Architects of Annihilation: Auschwitz and the Logic of Destruction. Trans. A. G. Blunden. Princeton: Princeton University Press, 2002.

—. Vordenker der Vernichtung: Auschwitz und die deutschen Pläne für eine neue europäische Ordnung. Hamburg: Hoffmann \& Campe, 1991.

Bailey, Liberty Hyde. Cross-Breeding and Hybridizing: The Philosophy of the Crossing of Plants, Considered With Reference to Their Improvement Under Cultivation. With a brief bibliography of the subject. New York: Rural Publishing, 1892.

Bonneuil, Christophe. "Mendelism, Plant Breeding and Experimental Cultures: Agriculture and the Development of Genetics in France." Journal of the History of Biology 39, no. 2 (2006): 281-308.

Coen, Deborah R. Vienna in the Age of Uncertainty: Science, Liberalism, and Private Life. Chicago: University of Chicago Press, 2007.

Correns, Carl. "G. Mendel's Regel über das Verhalten der Nachkommenschaft der Rassenbastarde." 1900. In Fundamenta Genetica: The Revised Edition of Mendel's Classic Paper, With a Collection of 27 Original Papers Published During the Rediscovery Era, edited by Jaroslav Kř́žženecký. With an 
introduction by Bohumil Němec, 103-112. Prague: Czechoslovak Academy of Sciences, 1965.

Ebner, Paulus. "Krise in Permanenz (1918-1945)." In Die Universität für Bodenkultur Wien: Von der Gründung in die Zukunft 1872-1997, edited by Manfred Welan and Paulus Ebner, 65-139. Vienna: Böhlau, 1997.

_. "Wiederaufbau und Stabilisierung 1945-1971." In Die Universität fur Bodenkultur Wien: Von der Gründung in die Zukunft 1872-1997, edited by Manfred Welan and Paulus Ebner, 140-170. Vienna: Böhlau, 1997.

Gayon, Jean and Doris T. Zallen. "The Role of the Vilmorin Company in the Promotion and Diffusion of the Experimental Science of Heredity in France, 1840-1920." Journal of the History of Biology 31, no. 2 (1998): 241-262.

Gliboff, Sander. "The Many Sides of Gregor Mendel." In Outsider Scientists: Routes to Innovation in Biology, edited by Oren Harman and Michael R. Dietrich, 27-44. Chicago: University of Chicago Press, 2013.

Harwood, Jonathan. "The Reception of Genetic Theory Among Academic Plant-Breeders in Germany, 1900-1930." Sveriges Utsädesförenings Tidskrift/Journal of the Swedish Seed Association 107 (1997): 187-195.

—. "The Rediscovery of Mendelism in Agricultural Context: Erich von Tschermak as Plant-Breeder." Comptes Rendus de l'Académie des Sciences, Series III: Sciences de la Vie 323, no. 12 (2000): 1061-1067.

Heim, Susanne. Calories, Caoutchouc, Careers: Plant Breeding and Agrarian Research in Kaiser-Wilhelm-Institutes, 1933-1945. Trans. Sorcha O'Hagan. Göttingen: Wallstein, 2003. Reprint, Springer, 2008.

Hofer, Veronika. "Mendelism and Eugenics in Vienna: Mendel's Rediscoverer Erich Tschermak-Seysenegg and his Active Involvement with Eugenics." Presented at the annual meeting of the History of Science Society, Montreal, November 6, 2010.

Kimmelman, Barbara A. "The Influence of Agricultural Practice on the Development of Genetic Theory." Sveriges Utsädesförenings Tidskrift/Journal of the Swedish Seed Association 107 (1997): 178-185.

Křruženecký, Jaroslav, editor. Fundamenta Genetica: The Revised Edition of Mendel's Classic Paper, With a Collection of 27 Original Papers Published During the Rediscovery Era. With an introduction by Bohumil Němec. Prague: Czechoslovak Academy of Sciences, 1965. 
Monaghan, Floyd and Alain Corcos. "Tschermak: A Non-Discoverer of Mendelism, I: An Historical Note." Journal of Heredity 77 (1986): 468-469.

_ . "Tschermak: A Non-Discoverer of Mendelism, II: A Critique." Journal of Heredity 78 (1987): 208-210.

Morgan, Thomas Hunt. "What are 'Factors' in Mendelian Explanations?" American Breeders Association Reports 5 (1909): 365-368.

Nilsson-Ehle, Hermann. "Einige Züge aus der Entwicklung des Mendelismus." Naturwissenschaften 12, no. 38 (1924): 757-761.

Olby, Robert C. "Mendel No Mendelian?" History of Science 17 (1979): 53-72.

. "Mendelism: From Hybrids and Trade to a Science." Comptes Rendus de l'Académie des Sciences, Series III: Sciences de la Vie 323, no. 12 (2000): 1043-1051.

Onaga, Lisa. "Toyama Kametaro and Vernon Kellogg: Silkworm Inheritance in Japan, Siam, and the United States, 1900-1912." Journal of the History of Biology 43, no. 2 (2010): 215-264.

Orel, Vítězslav. "Constant Hybrids in Mendel's Research." History and Philosophy of the Life Sciences 20 (1998): 291-299.

Palladino, Paolo. "Wizards and Devotees: On the Mendelian Theory of Inheritance and the Professionalization of Agricultural Science in Great Britain and the United States, 1880-1930." History of Science 32, no. 4 (1994): 409-444.

Paul, Diane B. and Barbara A. Kimmelman. "Mendel in America: Theory and Practice, 1900-1919." In The American Development of Biology, edited by Ronald Rainger, Keith R. Benson, and Jane Maienschein, 281-310. Philadelphia: University of Pennsylvania Press, 1988.

Roberts, Herbert F. Plant Hybridization before Mendel. Princeton: Princeton University Press, 1929.

Roll-Hansen, Nils. "The Role of Genetic Theory in the Success of the Svalöf Plant Breeding Program." Sveriges Utsädesförenings Tidskrift/Journal of the Swedish Seed Association 107 (1997): 196-206.

Ruckenbauer, Peter. "E. von Tschermak-Seysenegg and the Austrian Contribution to Plant Breeding." Vorträge für Pflanzenzüchtung 48 (2000): 3146. 
Simunek, Michal, Uwe Hoßffeld, and Volker Wissemann. "'Rediscovery' Revised: The Cooperation of Erich and Armin von Tschermak-Seysenegg in the Context of the 'Rediscovery' of Mendel's Laws in 1899-1901." Plant Biology 13, no. 6 (2011): 835-841.

Simunek, Michal et al., editors. The Mendelian Dioskuri: Correspondence of Armin with Erich von Tschermak-Seysenegg, 1898-1951. Prague: Institute of Contemporary History of the Academy of Sciences, Prague, and Department of Genetics/"Mendelianum" of the Moravian Museum, Brno, 2011.

Stern, Curt and Eva R. Sherwood, editors. The Origin of Genetics: A Mendel Source Book. San Francisco: W. H. Freeman, 1966.

Stubbe, Hans. "Erich von Tschermak-Seysenegg zum 70. Geburtstage." Naturwissenschaften 29, nos. 45-46 (1942): 696.

Teppner, Herwig. "Cucurbita pepo: History and Thin Coated Seeds." Cucurbit Genetics Cooperative Report 23 (2000): 126-127.

—. "Notes on Lagenaria and Cucurbita (Cucurbitaceae): Review and New Contributions." Phyton 44, no. 2 (2004): 245-308.

Theunissen, Bert. "Darwin and His Pigeons: The Analogy Between Artificial and Natural Selection Revisited." Journal of the History of Biology 45, no. 2 (2012): 179-212.

Tschermak, Erich. "Die Lehre von den formbildenden Faktoren (Variation, Anpassung, Selektion, Mutation, Kreuzung) und ihre Bedeutung für die 'rationelle' Pflanzenzüchtung." Jahrbuch der landwirtschaftlichen Pflanzenund Tierzüchtung 1 (1903): 30-45.

—. "Methoden der Veredelung und Neuzüchtung landwirthschaftlicher Gewächse." Wiener landwirthschaftliche Zeitung: Illustrierte Zeitung für die gesamte Landwirthschaft, March 30, 1898. Differs from the offprint in the Österreichische Nationalbibliothek.

—_. "Ueber künstliche Kreuzung bei Pisum sativum." Zeitschrift für das landwirtschaftliche Versuchswesen in Österreich 3 (1900): 465-555.

__. "Ueber Züchtung neuer Getreiderassen mittelst künstlicher Kreuzung: Kritisch-historische Betrachtungen." Zeitschrift für das landwirtschaftliche Versuchswesen in Österreich 4 (1901): 1029-1060.

Tschermak-Seysenegg, Erich. "Zum 25jährigen Bestehen der Gesellschaft für Pflanzenzüchtung 'Z' Wien." Der Züchter 9, nos. 6-7 (1937): 137-144. 
Tschermak-Seysenegg, Erich von. "Die Einwirkung der Wiederentdeckung der Mendelschen Gesetze auf Pflanzenbau und Pflanzenzüchtung." Kühn-Archiv: Arbeiten aus dem Landwirtschaftlichen Institut der Universität Halle 53 (1940): 1-13.

- Leben und Wirken eines Österreichischen Pflanzenzüchters: Beitrag zur Geschichte der Wiederentdeckung der Mendelschen Gesetze und ihre Anwendung in der Pflanzenzüchtung. Berlin: Paul Parey, 1958.

Tschermak-Seysenegg, Erich von. "The Rediscovery of Mendel's Work: An Historical Retrospect." Journal of Heredity 42, no. 4 (1951): 163-171.

_. "Wien als Ausgangsort des praktischen Mendelismus." Böhmen und Mähren: Blatt des Reichsprotektors in Böhmen und Mähren, Juli/August 1942, 242-244. From a copy in the Tschermak Papers, box 15.

Wieland, Thomas. "Scientific Theory and Agricultural Practice: Plant Breeding in Germany from the Late $19^{\text {th }}$ to the Early $20^{\text {th }}$ Century." In "Biology and Agriculture." Journal of the History of Biology 39, no. 2 (2006): 309-343.

Winkler, Joanna. "The Origin and Breeding of the Hull-less Seeded Styrian Oil-Pumpkin Varieties in Austria." Cucurbit Genetics Cooperative Report 23 (2000): 101-104.

Wood, Roger J. and Vítězslav Orel. Genetic Prehistory in Selective Breeding: A Prelude to Mendel. Oxford: Oxford University Press, 2001.

. "Scientific Breeding in Central Europe During the Early Nineteenth Century: Background to Mendel's Later Work." Journal of the History of Biology 38, no. 2 (2005): 239-272. 